\section{Penstemon: A Summary of Interspecific Crosses}

\author{
Dale T. Lindgren ${ }^{1,3}$ and Daniel M. Schaaf ${ }^{2}$ \\ University of Nebraska-Lincoln, West Central Research and Extension \\ Center, $461 \mathrm{~W}$. University Drive, North Platte, NE 69101-7756
}

Additional index words. classification, hybrids, species

\begin{abstract}
Documenting the successful interspecific crosses in a genus is a valuable tool in making decisions in developing strategies for plant breeding activities. However, summarizing the breeding and hybridization can be confusing because of incomplete or lost breeding records and the failure to register the parentage of new cultivar names. A summary of interspecific crosses in the genus Penstemon at the University of NebraskaLincoln West Central Research and Extension Center over 10 years provides insight into both successful and unsuccessful crosses. The results, based on seed production and percent of successful crosses, would suggest that interspecific crosses are more likely to be successful when the parent species are more closely related.
\end{abstract}

Penstemon Mitchell, a genus of highly divergent plants, is increasing in popularity, as documented by the number of newly released Penstemon cultivars and the number of recently published books on Penstemon (Lindgren and Wilde, 2003; Nold, 1999; Way and James, 1998). Many Penstemon crosses and hybrids have been reported (Lindgren, 2006). However, summarizing the breeding and hybridization in the genus Penstemon can be confusing because of incomplete or lost breeding records and the failure to register new Penstemon cultivar names with the appropriate authority (Lindgren, 1993). In addition, the correct parentage of "natural hybrids" is rarely known with certainty.

Interspecific hybrids offer the opportunity to expand the choice of plants available in any one genus. They can extend the flowering season, offer novel flower colors, expand the range of disease tolerance, generate new combinations of useful traits, and offer additional germplasm for adaptation to soil, climate, and moisture extremes. Cronquist et al. (1984) indicate that cross-breeding experiments could lead to reorganization in species classification in the genus Penstemon. Penstemon hybrids may also be valuable in determining evolutionary relationships in this genus (Wolfe et al., 2006). Bridging, during which one hybrid enables the breakdown of genetic barriers to incorporate other species into a Penstemon breeding complex, demonstrates the potential value Penstemon hybrids can have (Viehmeyer, 1958).

An initial summary of Penstemon hybridization, based on a standard Penstemon clas-

\footnotetext{
Received for publication 6 Dec. 2006. Accepted for publication 19 Feb. 2007.

A contribution of the University of Nebraska Agricultural Research Division, supported in part by funds provided through the Hatch Act. ${ }^{1}$ Professor.

${ }^{2}$ Research technician.

${ }^{3}$ To whom reprint requests should be addressed; e-mail dlindgren1@unl.edu
}

sification system, has been reviewed by Lindgren (2000). This summary discussed six general classes: 1) Dasanthera (Raf.) Penn. subgenus hybrids, 2) Penstemon Mitchell section hybrids, 3) Peltanthera Keck section hybrids, 4) Flathead Lake hybrids, 5) Gloxinoide-type hybrids, and 6) miscellaneous hybrids. Several other summaries relating to Penstemon hybrids have been published (Moore, 1980; Vesall, 1990; Viehmeyer, 1958).

Way and James (1998) discussed and summarized many of the European Penstemon hybrids. Species parents most often mentioned for the European hybrids include $P$. hartwegii Benth., P. gentianoides (Humboldt, Bonpland \& Kunth) Poiret, $P$. kunthii G. Don, P. campanulatus (Cav.) Willd., $P$. isophyllus Robinson, and P. cobaea Nutt. At the University of Nebraska-Lincoln (UNL) West Central Research and Extension Center (WCREC), a significant number of crosses/pollinations have been made in the genus Penstemon since the breeding and selection project was initiated. These include crosses between plants of different species, crosses between pure species and hybrids, and crosses between hybrids and other hybrids. The objective of this report is to summarize the interspecific crosses in the genus Penstemon at the UNL WCREC over 10 years, 1996-2005, and compare those results to other reports in the literature. The majority of species used in the crosses at the UNL WCREC have some adaptation to the high plains area of the Midwest United States and are, in general, assigned to a relatively few subsections. Species not well adapted to Nebraska were, in most cases, not used because of their low adaptability to Midwest growing conditions (e.g., low temperature, soil $\mathrm{pH}$, drought). Crosses were made to maximize the production of potentially new ornamental plants, not to develop a systematic method to evaluate crossability across taxonomic units. This approach led to a disproportionate large number of pollinations in some crossing groups and few in other crossing groups.

Species in the genus Penstemon can be grouped according to subgenera, sections, and subsections (Table 1). There are six subgenera, 13 sections, and 22 subsections in the genus (Lindgren and Wilde, 2003; Lodewick and Lodewick, 1999). Some subgenera are not divided into sections and not all sections are divided into subsections. Two subgenera, Cryptostemon and Dissecti, are monotypic (Wolfe et al., 2006).

\section{Materials and Methods}

The methods used to conduct the Penstemon pollinations in the UNL WCREC trials have been described by Lindgren (2000). Records were kept on the dates of pollination, seed harvest, and amount of seeds harvested from each cross. Records on seed germination and on seedling performance are a crucial part of the breeding program. However, these will be reported in detail in a separate publication. Only crosses of species to species are included in this report (Tables 2-4). Hybrids as parents were not included in the results because of the unknown parentage of some hybrids. Species that were selfed were also not included.

The comparisons between crosses in the various groups in this report are based on the percent of successful crosses and average seeds produced per cross. Groups of crosses, with small numbers for comparisons, were not always included in a discussion of the results because of inadequate numbers from which to draw conclusions. Because of the low number of species in some taxonomic groups, and a high number of species in other taxonomic groups, there is a lack of uniformity between groups and within groups that precludes statistical comparisons for percent fruit set and average seed production. In total, 31 species in the subgenus Penstemon $(\approx 182$ spp.), 12 species in the subgenus Habroanthus ( $\approx 50 \mathrm{spp}$.), five species in the subgenus Saccanthera $(\approx 28 \mathrm{spp}$.), and one species in the subgenus Dasanthera $(\approx 9$ spp.) were used in these studies.

\section{Results and Discussion}

The summary of Penstemon interspecific, species-to-species crosses, based on comparisons between subgenus groups, is listed in Table 2. Habroanthus $\times$ Habroanthus had the highest percent of successful crosses (40\%), and Penstemon $\times$ Penstemon had the highest average for seeds produced per cross (31.1). Subgenus crosses between Habroanthus $\times$ Saccanthera and the reciprocal cross produced no seed.

Comparisons of crosses of species to species within and between sections are summarized in Table 3, which is a further subdivision of Table 2. Crosses with the highest percentage of success, based on section divisions, were Elmigera $\times$ Cristati $(62 \%)$, 
Table 1. Penstemon classification. ${ }^{\mathrm{z}}$

\begin{tabular}{|c|c|c|}
\hline Subgenera & Sections & Subsections \\
\hline \multicolumn{3}{|l|}{ Cryptostemon (Keck) Keck } \\
\hline \multicolumn{3}{|l|}{ Dissecti (Penn.) N. Holm. } \\
\hline \multicolumn{3}{|l|}{ Dasanthera (Raf.) Penn. } \\
\hline \multirow[t]{3}{*}{ Saccanthera (Benth.) Gray } & Bridgesiani (Rydb.) Penn. & \\
\hline & Saccanthera Benth. & Serrulati Keck \\
\hline & & Heterophylli Penn. \\
\hline \multirow[t]{2}{*}{ Habroanthus (Keck) Crossw. } & Glabri (Rydb.) Penn. & \\
\hline & Elmigera (Rchb.) Benth. & \\
\hline \multirow[t]{25}{*}{ Penstemon Mitchell } & Ambigui (Rydb.) Penn. & \\
\hline & Baccharifolii Penn. & \\
\hline & Chamaeleon Crossw. & \\
\hline & Coerulei Penn. & \\
\hline & Cristati (Rydb.) Penn. & \\
\hline & Ericopsis Keck & Caespitosi (Rydb.) Keck \\
\hline & & Ericopsis Keck \\
\hline & & Linarioides Keck \\
\hline & Fasciculus Keck ex Straw & Campanulati Straw \\
\hline & & Fasciculi Straw \\
\hline & & Perfoliati Straw \\
\hline & & Racemosi Benth. \\
\hline & Peltanthera Keck & Centranthifolii (Benth.) Benth \\
\hline & & Havardiani Keck \\
\hline & & Peltanthera Keck \\
\hline & & Petiolati (Rydb.) Keck \\
\hline & Penstemon Mitchell & Arenarii Keck \\
\hline & & Deusti (Penn.) Keck \\
\hline & & Gairdneri Keck \\
\hline & & Harbouriani (Rydb.) Bennett \\
\hline & & Humiles Keck \\
\hline & & Multiflori (Penn.) Bennett \\
\hline & & Penstemon Mitchell \\
\hline & & Proceri Keck \\
\hline & & Tubaeflori Penn. \\
\hline
\end{tabular}

${ }^{\text {z} S o u r c e ~ o f ~ a u t h o r i t i e s ~ i s ~ L o d e w i c k ~ a n d ~ L o d e w i c k ~(1999) . ~}$

Peltanthera $\times$ Cristati $(30 \%)$, Coerulei $\times$ Penstemon (26\%), Penstemon $\times$ Glabri $(26 \%)$, and Peltanthera $\times$ Peltanthera $(24 \%)$. Section crosses with the highest average seed production per cross were Peltanthera $\times$ Peltanthera (53.7), Penstemon $\times$ Penstemon (47.1), and Penstemon $\times$ Coerulei (46.3).

Comparisons of species-to-species crosses based on subsection groups are summarized in Table 4, which is a subdivision of Table 3. The most successful crosses were Peltanthera $\times$ Peltanthera $(100 \%)$, Peltanthera $\times$ Cristati $(41 \%)$, and Penstemon $\times$ Glabri (26\%). Crosses with the highest number of seeds produced per cross for subsections were Penstemon $\times$ Penstemon (170.5), Glabri $\times$ Glabri (83.5), Penstemon $\times$ Coerulei (46.3), Tubaeflori $\times$ Penstemon (45.7),
Peltanthera $\times$ Peltanthera (32.8), and Penstemon $\times$ Glabri (29.4).

The results would suggest that interspecific crosses are more likely to be successful if the species are in the same subgenus, section, or subsection. For example, species in the subgenus Penstemon, section Penstemon, and subsection Penstemon had a relatively high chance of producing successful crosses with one another. This occurred also in the subgenus Habroanthus $\times$ Habroanthus, in the section Peltanthera $\times$ Peltanthera, and in the subsections Glabri $\times$ Glabri and Peltanthera $\times$ Peltanthera. Meyers (1998) also reported that most species within a section would cross with each other. These data partly support that theory. It is difficult to make comparisons between subgenus ver- sus section versus subsection crosses because of unequal classifications. However, seed produced with Penstemon $\times$ Penstemon increased as species were more closely related; subgenus, 31.1 seeds/cross; section, 47.1 seeds/cross; and subsection, 170.5 seeds/cross. For Glabri, the number of seeds per cross was 41.8 in sections and 83.5 in subsections. It was difficult to make reliable comparisons of reciprocal crosses with each other, in this summary, because of the unequal number of plants available and because of the limited amount of pollen that some plants produced. However, there appeared to be no difference in reciprocal crosses between individual species for percent of successful seed production.

Viehmeyer (1958) discussed the high probability of combining large-seed species with each other and the possibility of hybridizing small-seed species with each other. Penstemon species with seed of similar size tend to be more closely related. In this study, small-seed species such as $P$. digitalis Nutt., $P$. gracilis Nutt., P. hirsutus (L.) Willd., $P$. pallidus Small, and $P$. tenuis Small crossed readily with each other.

The classification scheme used in this study is based on the currently accepted taxonomic system within the genus Penstemon (Lindgren and Wilde, 2003). However, new taxonomic affinities recently reported may change the current thinking for the classification placement of some species (Wolfe et al., 2006). These changes could affect some of the relationships defined herein. Some of the species combinations attempted may either be more closely or less closely related, based on the study of Wolfe et al. (2006) with possible revision because of species changes.

As a general observation, crosses between species more closely related to each other produced progeny that were similar to the parents, especially for flower color and flower size. Examples of this are in the subsection crosses of Penstemon $\times$ Penstemon and Peltanthera $\times$ Peltanthera. Crosses between $P$. hirsutus, $P$. pallidus, $P$. gracilis, $P$. digitalis, and $P$. tenuis, all in the subsection Penstemon, produced progeny that were little different from the parents. The same can be said for species in the subsection

Table 2. Summary of pollinations between subgenus groups in the genus Penstemon.

\begin{tabular}{|c|c|c|c|c|c|}
\hline Cross & $\begin{array}{l}\text { Crosses } \\
\text { (n) }\end{array}$ & $\begin{array}{c}\text { Successful crosses } \\
\text { (n) }\end{array}$ & $\begin{array}{l}\text { Seeds Produced } \\
\text { (n) }\end{array}$ & $\begin{array}{c}\text { Percent successful } \\
\text { crosses }\end{array}$ & $\begin{array}{l}\text { Average seeds/cross } \\
\text { (n) }\end{array}$ \\
\hline \multicolumn{6}{|l|}{ Female parent $\times$ male parent } \\
\hline Dasanthera $(1) \times$ Habroanthus $(1)^{\mathrm{z}}$ & 1 & 1 & 3 & 100 & 3 \\
\hline Dasanthera $(1) \times$ Penstemon $(3)$ & 10 & 3 & 11 & 30 & 3.7 \\
\hline Habroanthus $(7) \times$ Habroanthus $(4)$ & 31 & 12 & 210 & 40 & 17.5 \\
\hline Habroanthus $(10) \times$ Penstemon $(16)$ & 371 & 74 & 484 & 20 & 6.5 \\
\hline Habroanthus $\times$ Saccanthera & 10 & 0 & 0 & 0 & 0 \\
\hline Penstemon $(2) \times$ Dasanthera $(1)$ & 6 & 2 & 9 & 33 & 4.5 \\
\hline Penstemon $(13) \times$ Habroanthus $(10)$ & 179 & 23 & 392 & 13 & 17.1 \\
\hline Penstemon $(22) \times$ Penstemon $(23)$ & 2500 & 292 & 9083 & 12 & 31.1 \\
\hline Penstemon $(9) \times$ Saccanthera $(5)$ & 40 & 7 & 157 & 18 & 22.4 \\
\hline Saccanthera $(2) \times$ Habroanthus $(1)$ & 11 & 0 & 0 & 0 & 0 \\
\hline Saccanthera $(4) \times$ Penstemon $(15)$ & 215 & 6 & 73 & 3 & 12.2 \\
\hline Saccanthera $(2) \times$ Saccanthera $(2)$ & 4 & 1 & 2 & 25 & 2 \\
\hline
\end{tabular}

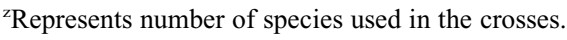


Table 3. Summary of pollinations between sections in the genus Penstemon.

\begin{tabular}{|c|c|c|c|c|c|c|}
\hline Female parent & Male parent & Crosses made (n) & Good (n) & Seeds (n) & Percent good & Seeds/cross (n) \\
\hline Coerulei & Bridgesiani & 1 & 0 & 0 & 0 & 0 \\
\hline Coerulei & Cristati & 7 & 2 & 36 & 29 & 18 \\
\hline Coerulei & Glabri & 2 & 1 & 71 & 50 & 71 \\
\hline Coerulei & Peltanthera & 10 & 3 & 86 & 30 & 28.7 \\
\hline Coerulei & Penstemon & 19 & 5 & 110 & 26 & 22 \\
\hline Cristati & Coerulei & 4 & 1 & 1 & 25 & 1 \\
\hline Cristati & Cristati & 3 & 0 & 0 & 0 & 0 \\
\hline Cristati & Glabri & 2 & 0 & 0 & 0 & 0 \\
\hline Cristati & Peltanthera & 13 & 1 & 17 & 8 & 17 \\
\hline Cristati & Penstemon & 8 & 1 & 1 & 13 & 1 \\
\hline Cristati & Saccanthera & 3 & 0 & 0 & 0 & 0 \\
\hline Elmigera & Coerulei & 2 & 0 & 0 & 0 & 0 \\
\hline Elmigera & Cristati & 76 & 47 & 393 & 62 & 8.4 \\
\hline Elmigera & Elmigera & 10 & 4 & 24 & 40 & 6 \\
\hline Elmigera & Glabri & 1 & 1 & 11 & 100 & 11 \\
\hline Elmigera & Peltanthera & 28 & 4 & 6 & 14 & 1.5 \\
\hline Elmigera & Penstemon & 64 & 3 & 3 & 5 & 1 \\
\hline Elmigera & Saccanthera & 3 & 0 & 0 & 0 & 0 \\
\hline Ericopsis & Peltanthera & 1 & 0 & 0 & 0 & 0 \\
\hline Ericopsis & Penstemon & 2 & 0 & 0 & 0 & 0 \\
\hline Glabri & Bridgesiani & 2 & 0 & 0 & 0 & 0 \\
\hline Glabri & Coerulei & 11 & 0 & 0 & 0 & 0 \\
\hline Glabri & Cristati & 46 & 8 & 43 & 17 & 5.4 \\
\hline Glabri & Elmigera & 16 & 3 & 8 & 19 & 2.7 \\
\hline Glabri & Glabri & 5 & 4 & 167 & 80 & 41.8 \\
\hline Glabri & Peltanthera & 52 & 6 & 16 & 12 & 2.7 \\
\hline Glabri & Penstemon & 42 & 5 & 23 & 12 & 4.6 \\
\hline Glabri & Saccanthera & 5 & 0 & 0 & 0 & 0 \\
\hline Dasanthera & Cristati & 3 & 1 & 3 & 33 & 3 \\
\hline Dasanthera & Glabri & 1 & 1 & 3 & 100 & 3 \\
\hline Dasanthera & Peltanthera & 6 & 1 & 6 & 17 & 6 \\
\hline Dasanthera & Penstemon & 1 & 1 & 2 & 100 & 2 \\
\hline Peltanthera & Bridgesiani & 6 & 2 & 9 & 33 & 4.5 \\
\hline Peltanthera & Coerulei & 35 & 1 & 32 & 3 & 32 \\
\hline Peltanthera & Cristati & 43 & 13 & 217 & 30 & 16.7 \\
\hline Peltanthera & Elmigera & 16 & 0 & 0 & 0 & 0 \\
\hline Peltanthera & Glabri & 7 & 2 & 31 & 29 & 15.5 \\
\hline Peltanthera & Peltanthera & 37 & 9 & 483 & 24 & 53.7 \\
\hline Peltanthera & Penstemon & 119 & 8 & 54 & 7 & 6.8 \\
\hline Peltanthera & Saccanthera & 5 & 2 & 123 & 40 & 61.5 \\
\hline Penstemon & Bridgesiani & 14 & 1 & 22 & 7 & 22 \\
\hline Penstemon & Coerulei & 144 & 10 & 463 & 7 & 46.3 \\
\hline Penstemon & Cristati & 560 & 42 & 278 & 8 & 6.6 \\
\hline Penstemon & Elmigera & 125 & 13 & 84 & 10 & 6.5 \\
\hline Penstemon & Ericopsis & 3 & 0 & 0 & 0 & 0 \\
\hline Penstemon & Glabri & 27 & 7 & 206 & 26 & 29.4 \\
\hline Penstemon & Peltanthera & 747 & 50 & 418 & 7 & 8.4 \\
\hline Penstemon & Penstemon & 739 & 148 & 6970 & 20 & 47.1 \\
\hline Penstemon & Saccanthera & 11 & 2 & 12 & 18 & 6 \\
\hline Penstemon & Dasanthera & 6 & 2 & 9 & 33 & 4.5 \\
\hline Saccanthera & Coerulei & 2 & 0 & 0 & 0 & 0 \\
\hline Saccanthera & Cristati & 68 & 1 & 3 & 1 & 3 \\
\hline Saccanthera & Elmigera & 11 & 0 & 0 & 0 & 0 \\
\hline Saccanthera & Fasciculus & 7 & 0 & 0 & 0 & 0 \\
\hline Saccanthera & Peltanthera & 69 & 2 & 4 & 3 & 2 \\
\hline Saccanthera & Penstemon & 69 & 3 & 66 & 4 & 22 \\
\hline Saccanthera & Saccanthera & 4 & 1 & 2 & 25 & 2 \\
\hline
\end{tabular}

Peltanthera, including the species $P$. palmeri Gray, P. floridus Brandeg., P. pseudospectabilis M.E. Jones, and P. clutei A. Nels.

A few brief comments on the general performance of the progeny from the species crosses will be useful in interpreting the information provided here. In this project, only about $13 \%$ of the crosses produced seed, and very few Penstemon plants have been selected from the seedling populations for further evaluation. Many of the seedlings had intermediate traits for adaptation, lacking their parents' traits for adaptation; some progeny exhibited more disease than either parent; some were short lived compared with either parent; others lacked architectural sturdiness; and some had flowers that were less attractive than either parent. Most of these progeny produced few seeds. Natural selection over many years has developed many Penstemon species that are adapted to specific sites. Crossing of species to species may cause a loss of specifically adapted traits as found in the parents.

Crosses between species more distantly related to each other produced some of the more interesting and promising new progeny. Although more details will be presented on progeny performance in another publication, a few comments may be valuable to share here. Parents that have been successful in producing unique progeny in this program are $P$. cobaea, P. triflorus A.A. Heller, $P$. barbatus (Cav.) Roth, P. digitalis Nutt., $P$. tubaeflorus Nutt., P. clutei A. Nels., and $P$. strictus Benth. In addition, the Mexican species $P$. hidalgensis crosses with the Mexicana and Mexicali groups, producing especially nice hybrids. Penstemon cobaea has also been reported to be a successful parent in the European hybrids (Way and James, 1998). 
Table 4. Summary of pollinations between subsections in the genus Penstemon.

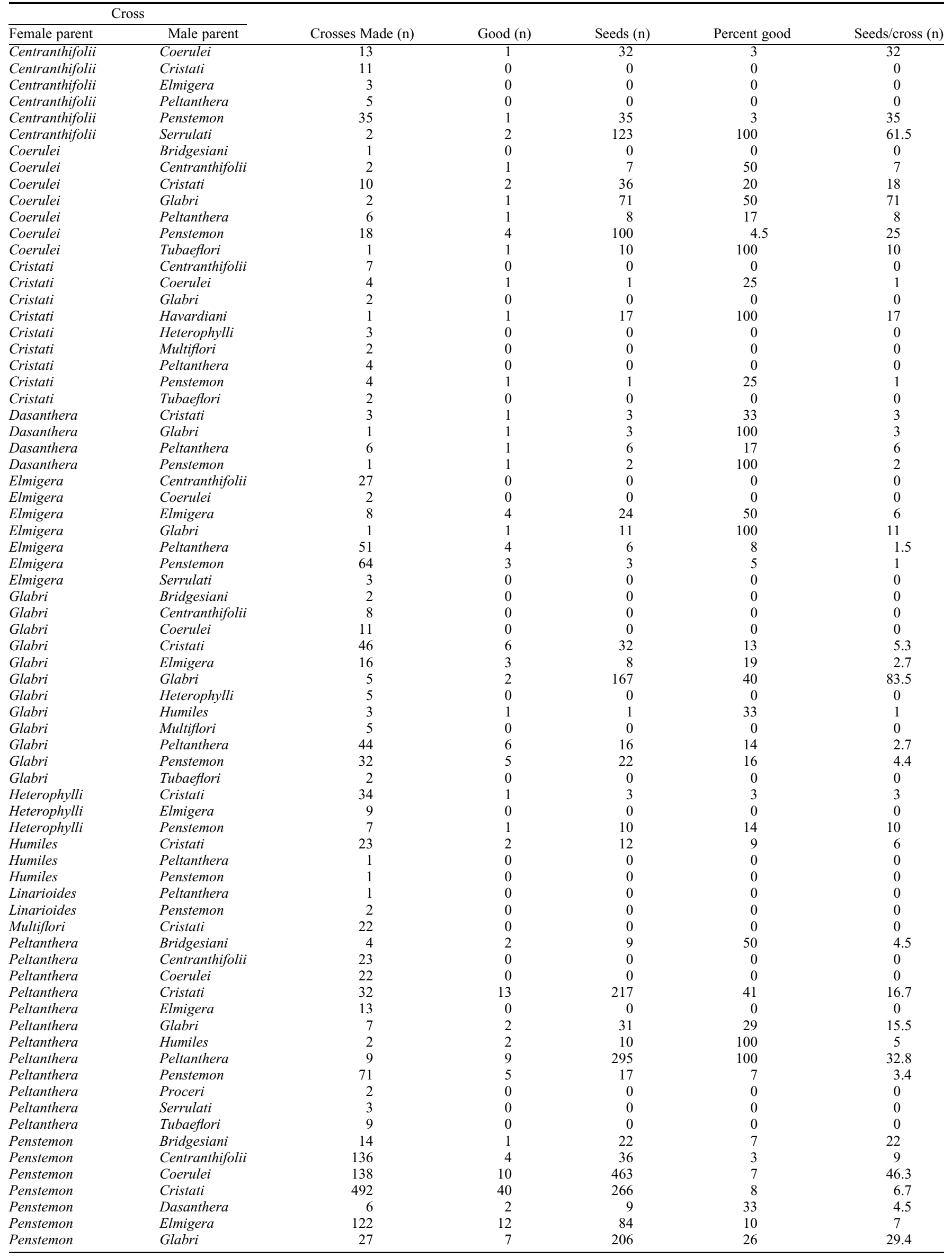

(Continued on next page) 
Table 4. (Continued) Summary of pollinations between subsections in the genus Penstemon.

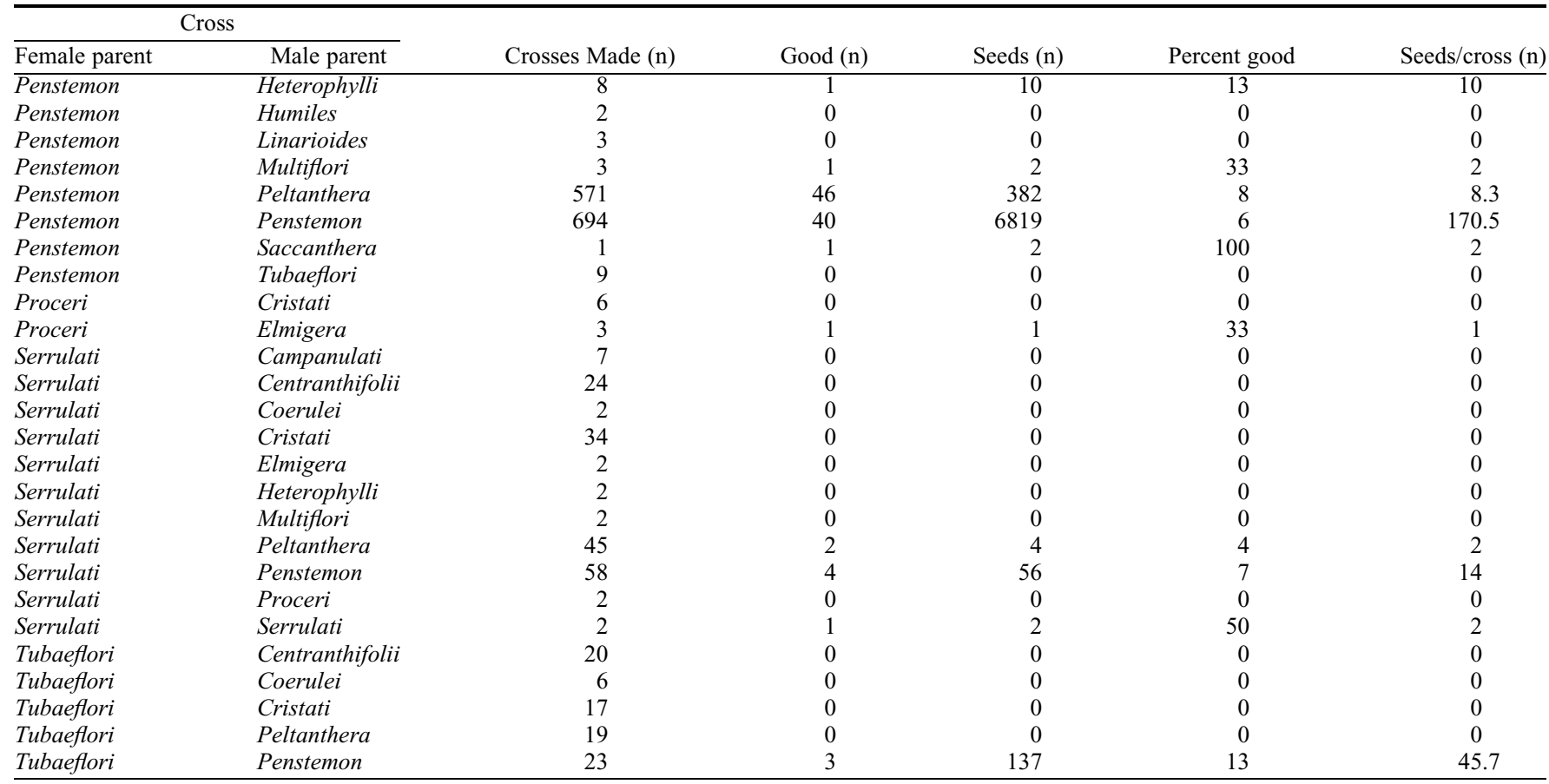

Hybridization in the genus Penstemon is complex. Success can be based on the number of successful crosses and seed produced per cross, but the ultimate test is producing new hybrids. In this program, the percentage of seed that germinated was low. Many seedlings had low vigor and performed poorly. However, persistence is needed in hybridizing Penstemon species and overcoming barriers to interspecific crosses of Penstemon.

\section{Literature Cited}

Cronquist, A., A.H. Holmgren, N.H. Holmgren, J.L. Reveal, and P.K. Holmgren. 1984. Intermountain flora: Vascular plants of the intermountain West, USA. Vol. 4. New York Botanical Garden, Bronx, N.Y.
Lindgren, D.T. 1993. The need to register new cultivar names: Penstemon, a case study. HortScience 28:82-83.

Lindgren, D.T. 2000. Breeding Penstemon, p. 196 212. Breeding ornamental plants. Timber Press, Portland, Ore.

Lindgren, D. 2006. List and description of named cultivars in the genus Penstemon. University of Nebraska Coop. Ext. EC1255, Univ. of Chicago Press, Chicago.

Lindgren, D. and E. Wilde. 2003. Growing Penstemons: Species, cultivars and hybrids. Amer. Penstemon Soc., InfinityPublishing.com, Haverford, Pa.

Lodewick, K. and R. Lodewick. 1999. Key to the genus Penstemon and its related genera in the tribe Cheloneae (Scrophulariaceae). K. Lodewick, Eugene, Ore.

Meyers, B. 1998. A summary of Bruce Meyers' Penstemon hybridizations. Bul. Amer. Penstemon Soc. 57:2-11.
Moore, G. 1980. Concerning Penstemon hybridization. Bul. Amer. Penstemon Soc. 39:12-16.

Nold, R. 1999. Penstemons. Timber Press. Portland, Ore.

Vesall, J. 1990. Dasanthera cultivars and hybrids. Bul. Amer. Penstemon Soc. 49: 3-12.

Viehmeyer, G. 1958. Reversal of evolution in the genus Penstemon. Amer. Naturalist 92:129137.

Way, D. and P. James. 1998. The gardener's guide to growing Penstemon. Timber Press, Portland, Ore.

Wolfe, A.D., C.R. Randle, S.L. Datwyler, J.J. Morawetz, N. Arguedas, and J. Diaz. 2006. Phylogeny, taxonomic affinities, and biogeography of Penstemon (Plantaginaceae) based on ITS and CPDNA sequence data. Amer. J. Bot. 93:1699-1713. 